\title{
THE "HIGH RISK" INFANT
}

\author{
C. D. MOLTENO, B.A., M.B.Ch.B., M.MED., M.D., F.C.P. (S.A.), D.C.H.*
}

\section{SUMMARY}

Today there is a far more positive attitude towards handicapped children. Together with this trend goes the necessity of early diagnosis and comprehensive management. By considering certain infants to be at risk for developmental disabilities and by introducing population screening programmes, early detection becomes a possibility. In addition to diagnosis, adequate treatment facilities to cater for the children and their families should be established in all areas of the conntry.

Developmental disabilities are common in infancy and childhood and present a challenge to all those concerned with child health. When the disabilities are of a chronic, non-progressive nature, the child is described as being handicapped. A handicapped child is defined by Sheridan (1968) as one who sulfers from any continuing disability of body, intellect or personality which is likely to interfere with normal growth, development and the capacity to learn. In an eflort to effect early diagnosis of such children, Sheridan introduced the "at risk" concept in 1962. This concept was not however generally accepted because it was lound that, in order to detect most handicaps, $60-70 \%$ of infants had to be considered "at risk". This involved excessive expenditure of time and money as well as causing unnecessary maternal anxiety. Risk registers have therefore been replaced by population screening programmes.

According to Holt (I973), screening procedures are sensitive to and specific for a particular condition, capable of being performed quickly and cheaply and of providing a fail/pass result. They may be carried out in a G.P. consulting room or a well baby clinic by appropriately trained community nurses working under the supervision of a clinic doctor. If every infant was screened in the neonatal period by a doctor, at 6 months and again at a year by a community health nurse, most major handicaps would be cletected in infancy. Infants picked up by such screening should be referred to a developmental assessment unit.

The risk concept does, however, have merit. Early detection of cerebral palsy gives rise to better long-term results of therapy. Follow-up clinics catering for infants managed in neonatal intensive care units focus on those at particular risk for cerebral palsy. Such cases could be identified and therapy commenced in the first six months of life. It must be mentioned that therapy can begin before a definite diagnosis of cerebral palsy has been made.

Detection of neurodevelopmental abnormality indicates the need for neurodevelopmental therapy. Highrisk infants should be examined at certain key ages (corrected for prematurity where applicable) when problems are more easily detected. The following is not intended as a complete check list of all abnormal signs, but as an indication of the most common ones.

6 weeks:

- Feeding difficulties associated with extensor hypertonus, tongue thrust etc.

* Senior Lecturer and Paediatrician, Department of Paediatrics and Child Health, University of Cape Town and Red Cross War Memorial Children's Hospital.

Received 1 May 1981.

\section{OPSOMMING}

Vandag is die houding teenoor gestremde kinders baie meer positief. Dié neiging gaan saam met die noodsaaklikheid vir vroeë diagnose en omvattende hantering. Deur sekere suigelinge as hoë risiko vir ontwikkelingsgestremidhede te beskou en denr bevolkingssiftingprogramme in te stel, word vroee opsporing 'n moontlikheid. Behalwe diagnose, behoort voldoende behandelingfasiliteite vir die kinders en hulle families in al die dele van die land tot stand gebring te word.

\section{4 months:}

- Asymmetry of tone or movement.

- Persistent primitive reflexes, e.g. Moro, fisting, obligatory asymmetric tonic neck reflex (ATNR).

- Head lag in pull to sit due to hypotonia or extensor hypertonus. It is important to observe the feet during this procedure. They should lift off the bed when the infant is pulled up into the sitting position.

- Failure of visual pursuit movements (laterally and lip and down). It is useful to look for an obligatory ATNR during lateral visual following.

- Absent head righting on lateral tilting.

8 months:

- Absent lateral protective extension.

- Failure to grasp an object equally well with either hand.

\section{2 months:}

- By this stage all children with cerebral palsy should have been diagnosed and therapy commenced. The twelve-month examination is useful, however, in the case of premature infants who have been through a stage of extensor hypertonus. By a year it should have done so if it is going to resolve.

The scheme is cumulative, i.e., if any of the signs listed at a specific age are present at the next, they are abnormal.

The decision to treat a child depends on the presence of neurodevelopmental abnormality. This does not necessarily indicate a diagnosis of cerebral palsy. Such a diagnosis depends on both the neurodevelopmental picture and a formal neurological examination. The diagnosis should be made by a paediatric neurologist or a doctor trained in developmental paediatrics. The implications for the child and family of such a diagnosis are grave and it should only be made with confidence. On the other hand, once made, the parents are entitled to be informed immediately.

Cerebro-motor dysfunction is not the only type of abnormality which may present during infancy. Problems with vision, hearing or global developmental delay occur and should be detected. Vision and hearing can be tested clinically by the Stycar method and if delay found to be present, the child is referred to the relevant specialist. It is important to establish a developmental profile in all infants assessed. The assessment should include gross motor function, manipulation and social and language development.

The management, once a diagnosis of some form of handicap has been made, may be divided into that clirected towards the child himself and those aspects concerning the family as a whole. Regarding the former, space does not allow for a full description of the techniques of neurodevelopmental therapy. However, it is 
appropriate to consider the aims of treatment of cerebral palsy as described by Bobath (1967);

"1. To develop normal postural reactions and postural tone against gravity for support and control of movements.

2. To counteract the development of abnormal postural reactions and of abnormal postural tone.

3. To give the child, by means of handling and play, the functional patterns he will use later on for feeding, dressing, washing etc for self-help.

4. To prevent the development of contractures and deformities".

It is obvious that a comprehensive assessment of each child, outlining both abilities and disabilities, must preceed therapy. Similarly, periodic reassessment forms an integral part of neurodevelopmental therapy.

Management of the family includes parent counselling and education, and also practical help with day-to-day problems. Parent counselling should form an integral part of the management of every handicapped child and should be offered as soon as the handicap is diagnosed. It may take the form of formal counselling by a social worker, or psychologist or be conducted informally by the therapist treating the child. MacKeith (1973) describes the feelings of anger, grief, guilt and revulsion felt by parents faced with the shock of learning that their child is handicapped. Parents need an opportunity to discuss these feelings in order to adjust to what has happened and come to some sort or realistic acceptance. Without acceptance the parents will have difficulty finding resources within themselves to provide the kind of loving and secure environment their child needs.
Parents should be given as much information about their child's handicap as they request. The diagnosis and prognosis must be interpreted and discussed in terms which they understand. They also need to know what facilities are available and how to use them. The greatest source of anxiety in parents is uncertainty -. not knowing exactly what has happened nor what can be done about it.

Parents also require practical help with day-to-day problems of management, especially if the child is severely handicapped. Problems of feeding, discipline, the most suitable kind of play and toys, how to organise the daily routine so that other members of the family are not neglected, frequently arise.

The presence of a handicapped child in a family represents a human tragedy. Every effort should be made to prevent such a situation from occurring. However, when it does arise, early diagnosis and comprehensive management will lessen the impact, provide a much needed support system and facilitate acceptance by the parents and also promote the development of the child.

\section{References}

Bobath, B. (1967). The very early treatment of cerebral palsy. Develop. Med. Child Neurol. 9, 373.

Holt, K. S. (1973). Functional assessment of handicapped children: An assessment. Proc. Roy. Soc. Med. 66, 6II.

MacKeith, R. M. (1973). The feelings and behaviour of parents of handicapped children. Develop. Med Child Neurol. 4, 115.

Sheridan, M. D. (1968). The developmental progress of infants and young children. Ministry of Health Report. 20. 102. London. H.M.S.O. 